\title{
Optimum Dark Adaptation Period for Evaluating the Maximum Quantum Efficiency of Photosystem II in Ozone-Exposed Rice Leaves
}

\author{
Hiroki Kobayakawa, Katsu Imai* \\ School of Agriculture, Meiji University, Kawasaki, Japan. \\ Email: ${ }^{*}$ imai@isc.meiji.ac.jp \\ Received June $9^{\text {th }}, 2013$; revised July $9^{\text {th }}, 2013$; accepted August $10^{\text {th }}, 2013$
}

Copyright (C) 2013 Hiroki Kobayakawa, Katsu Imai. This is an open access article distributed under the Creative Commons Attribution License, which permits unrestricted use, distribution, and reproduction in any medium, provided the original work is properly cited.

\begin{abstract}
Because the transient $\mathrm{O}_{3}$ injury of leaves is lost with time, the evaluation of $\mathrm{O}_{3}$ effect on the maximum quantum efficiency of PSII $\left(F_{\mathrm{v}} / F_{\mathrm{m}}\right)$ is difficult. Thus, the authors examined $F_{\mathrm{v}} / F_{\mathrm{m}}$ in rice leaves exposed to different $\mathrm{O}_{3}$ concentrations $\left(0,0.1\right.$, and $0.3 \mathrm{~cm}^{3} \cdot \mathrm{m}^{-3}$, expressed as $\mathrm{O}^{0}, \mathrm{O}^{0.1}$, and $\left.\mathrm{O}^{0.3}\right)$ under different dark adaptation periods $(0,1,5,10,20$, and $30 \mathrm{~min}$, expressed as $\mathrm{D}^{0}, \mathrm{D}^{1}, \mathrm{D}^{5}, \mathrm{D}^{10}, \mathrm{D}^{20}$, and $\mathrm{D}^{30}$ ) to ascertain its optimum time span. $F_{\mathrm{v}} / F_{\mathrm{m}}$ was inhibited by $\mathrm{O}_{3}$; however in the $\mathrm{O}^{0}$ and $\mathrm{O}^{0.1}$ plants, it recovered during dark adaptation. In the $\mathrm{O}^{0.3}$ plants, $F_{\mathrm{v}} / F_{\mathrm{m}}$ decreased gradually with time. $F_{0}$ was found to be increased by $\mathrm{O}_{3}$, and it increased further in the $\mathrm{O}^{0.3}$ plants during dark adaptation. Under a high light intensity, $F_{\mathrm{m}}$ was decreased by $\mathrm{O}_{3}$, and the $\mathrm{O}_{3}$-induced damage to $F_{\mathrm{v}} / F_{\mathrm{m}}$ was therefore more pronounced. However, the sensitivity of $F_{\mathrm{m}}$ was lower than that of $F_{0}$. Consequently, the damage to PSII was mainly attributed to the inhibition of electron transport from $\mathrm{Q}_{\mathrm{A}}$ to $\mathrm{Q}_{\mathrm{B}}$. The $F_{\mathrm{v}} / F_{\mathrm{m}}$ ratio in the $\mathrm{O}^{0}$ plants was fully recovered at $\mathrm{D}^{10}$, and in the $\mathrm{O}^{0.1}$ plants, $F_{\mathrm{v}} / F_{\mathrm{m}}$ increased from $\mathrm{D}^{10}$ to $\mathrm{D}^{20}$. The effects of $\mathrm{O}_{3}$ on the xanthophyll cycle-dependent quenching (fast relaxation phase) of $\mathrm{q}_{\mathrm{I}}$ disappeared when the dark adaptation period was greater than 20 min. However, it was difficult to distinguish the effects of $\mathrm{O}_{3}$ and other factors (e.g., light) before $\mathrm{D}^{5}$. The current results demonstrate that the optimum dark adaptation period in rice leaves is $10 \mathrm{~min}$ because the effect of $\mathrm{O}_{3}$ remains maximal, while the effects of other factors on $F_{\mathrm{v}} / F_{\mathrm{m}}$ disappear during this period. By accurate measurement of $F_{\mathrm{v}} / F_{\mathrm{m}}$, the physiology of $\mathrm{O}_{3}$ effect on PSII in rice leaves is precisely evaluated.
\end{abstract}

Keywords: Dark-Adapted State; Oryza sativa; Ozone Stress; Photosystem II; Quantum Efficiency

\section{Introduction}

In the Kanto region of Japan, where rice is cultivated as a staple summer crop, 10 - 20 warnings regarding high photochemical oxidants $\left(\geqq 0.12 \mathrm{~cm}^{3} \cdot \mathrm{m}^{-3}\right)$ are received every growing season, and the hourly peak values of these substances are sometimes close to $0.2 \mathrm{~cm}^{3} \cdot \mathrm{m}^{-3}$ [1]. Overall, ozone $\left(\mathrm{O}_{3}\right)$ accounts for $90 \%$ or more of the total photochemical oxidants $[2,3]$. When exposed to $\mathrm{O}_{3}$, rice plants suffer damage caused by the inhibition of net photosynthetic rate $\left(P_{\mathrm{N}}\right)$ and photosystem II (PSII) [4,5] as well as decreases in the contents of ribulose 1,5-bisphosphate carboxylase/oxygenase [6], the contents of chlorophyll and carotenoids [7], and nitrite reductase activity [8], in addition to visible leaf-related symptoms [4] and

\footnotetext{
"Corresponding author.
}

breakdown of the cellular ultrastructure [9]. Moreover, $\mathrm{O}_{3}$ suppresses growth [10], alters photoassimilate partitioning [11], and decreases grain yield [10,12,13]. Detrimental effects of $\mathrm{O}_{3}$ have also been reported in many other crops and trees [14,15].

Because PSII of plants is deteriorated immediately after $\mathrm{O}_{3}$ exposure [5], the monitoring of PSII is useful as a tool to evaluate $\mathrm{O}_{3}$ damage and recovery from it. Recently, the examination of chlorophyll fluorescence measurements has become established practice for the diagnosis of changes in PSII caused by environmental stresses such as excessive light and water stress. Many studies assessing the effects of environmental stress on PSII have been conducted [16,17]. By analyzing chlorophyll fluorescence measurements, Kobayakawa and Imai [5] showed that the maximum $\left(F_{\mathrm{v}} / F_{\mathrm{m}}\right)$ and operating $\left(F_{\mathrm{q}}{ }^{\prime} / F_{\mathrm{m}}{ }^{\prime}\right)$ quan- 
tum efficiencies of PSII photochemistry were decreased by acute (5-h) $\mathrm{O}_{3}$ exposure. In addition, PSII in rice leaves is adversely affected by chronic $\mathrm{O}_{3}$ exposure [7]. Among the indicators obtained through performing chlorophyll fluorescence measurements, $F_{\mathrm{v}} / F_{\mathrm{m}}$ is used most frequently. $F_{\mathrm{v}} / F_{\mathrm{m}}$ is determined from the easiest and simplest type of chlorophyll fluorescence measurement. However, before such measurements can be obtained, knowledge regarding the dark adaptation period is required. When a leaf is kept in the dark, the primary quinone acceptor of PSII $\left(Q_{\mathrm{A}}\right)$ becomes maximally oxidized. The PSII reaction centers can then perform photochemical reduction of $Q_{\mathrm{A}}$, and the minimal fluorescence in the darkadapted state $\left(F_{0}\right)$ can be determined. Thereafter, when a leaf is exposed to a short actinic pulse of high PPFD (typically of less than $1 \mathrm{~s}$ at several thousand $\mu \mathrm{mol}$ $\left.\mathrm{m}^{-2} \cdot \mathrm{s}^{-1}\right), Q_{\mathrm{A}}$ reaches a maximally reduced state, and the maximal fluorescence in the dark-adapted state $\left(F_{\mathrm{m}}\right)$ can be determined. Baker [18] described variable fluorescence $\left(F_{\mathrm{v}}\right)$ as the difference between $F_{0}$ and $F_{\mathrm{m}}$ values. Generally, the dark adaptation period for the leaves subjected to this treatment is $30 \mathrm{~min}$. However, Sonoike [19] observed that if the dark adaptation period is prolonged, the effects of short-term stress on PSII will disappear. In fact, many researchers [20-29] have measured the effect of $\mathrm{O}_{3}$ on $F_{\mathrm{v}} / F_{\mathrm{m}}$ based on qualification of chlorophyll fluorescence under various dark adaptation periods, the shortest of which was $5 \mathrm{~min}$ [27], and the longest was $60 \mathrm{~min}$ $[23,28]$.

This study was conducted to establish the optimum dark adaptation period for measurement of the PSII $F_{\mathrm{v}} / F_{\mathrm{m}}$ in rice leaves under $\mathrm{O}_{3}$ stress or stress free conditions to clarify the inhibition and recovery of photosynthesis by $\mathrm{O}_{3}$.

\section{Materials and Methods}

\subsection{Plant Materials and Gas Exposure}

Two independent experiments were conducted in April and July 2012 and were designated Exp. 1 (April) and Exp. 2 (July). Japonica rice (Oryza sativa L. cv. Koshihikari) seeds were sown directly in Wagner pots (1/ $5000 \mathrm{a}$ ) filled with $2.2 \mathrm{~kg}$ of dry soil and $12.5 \mathrm{~g}$ of compound fertilizer $\left(\mathrm{N}, \mathrm{P}_{2} \mathrm{O}_{5}, \mathrm{~K}_{2} \mathrm{O}=8,8,8 \%\right)$. The seeds were grown in natural light, gas exposure chambers (width $\times$ depth $\times$ height $=2 \mathrm{~m} \times 2 \mathrm{~m} \times 1.9 \mathrm{~m}, \mathrm{~S}-2003 \mathrm{~A}$; Koito Industries, Ltd., Yokohama, Japan) at $28 / 23^{\circ} \mathrm{C}(12-\mathrm{h}$ day/12-h night) under $70 \% \mathrm{RH}$ and $400 \mathrm{~cm}^{3} \cdot \mathrm{m}^{-3} \mathrm{CO}_{2}$. Immediately after full expansion of the eighth leaves (Haun index $=8.0$ ) [30], the plants were exposed to 0 , 0.1 , or $0.3 \mathrm{~cm}^{3} \cdot \mathrm{m}^{-3} \mathrm{O}_{3}$ (expressed as $\mathrm{O}^{0}, \mathrm{O}^{0.1}$, and $\mathrm{O}^{0.3}$, respectively) for $5 \mathrm{~h}$ during the day (8:00 - 13:00 h local time). Ozone was supplied using a high voltage ozone generator with dry air (ED-OG-R6; Ecodesign Inc., Ogawa, Saitama, Japan). $\mathrm{CO}_{2}$ was supplied from cylinders containing liquid $\mathrm{CO}_{2}$. These gases were injected into air that had been charcoal-filtered. The $\mathrm{O}_{3}$ and $\mathrm{CO}_{2}$ concentrations were measured and computer controlled using an ultraviolet absorption-type $\mathrm{O}_{3}$ analyzer (EG-2001F; Ebara Jitsugyo, Tokyo, Japan) and an infrared $\mathrm{CO}_{2}$ analyzer (ZRH, Fuji Electric Systems, Tokyo, Japan), respectively.

\subsection{Chlorophyll Fluorescence Measurements}

A fluorometer (LI-6400-40; Li-Cor Inc., Lincoln, NE, USA) attached to a portable photosynthesis and transpiration measurement system (LI-6400XT; Li-Cor Inc., Lincoln, NE, USA) and a portable fluorometer (MINIPAM; Heinz Walz GmbH, Effeltrich, Germany) were used to measure the chlorophyll fluorescence of the eighth leaves from $0.1-1.1 \mathrm{~h}$ after $\mathrm{O}_{3}$ exposure for each of five replicate plants. Chlorophyll fluorescence parameters were determined in these plants by applying 0.2 and $7000 \mu \mathrm{mol} \cdot \mathrm{m}^{-2} \cdot \mathrm{s}^{-1}$ of measuring light and a saturating pulse $(0.8 \mathrm{~s})$. Prior to the fluorescence measurements, the leaves were kept in the dark for $0,1,5,10,20$, or 30 min (expressed as $\mathrm{D}^{0}, \mathrm{D}^{1}, \mathrm{D}^{5}, \mathrm{D}^{10}, \mathrm{D}^{20}$, and $\mathrm{D}^{30}$, respectively). Subsequently, $F_{0}$ and $F_{\mathrm{m}}$ were determined by irradiating the measuring light and saturating pulses, respectively. In addition to $F_{\mathrm{v}} / F_{\mathrm{m}},\left(1 / F_{0}\right)-\left(1 / F_{\mathrm{m}}\right)$ was calculated as an indicator of PSII photoinactivation $[18,19$, 31]. The dark adaptation treatments and fluorescence measurements were conducted at $28^{\circ} \mathrm{C}$. In Exp. 2, chlorophyll fluorescence was measured using only a portable fluorometer (MINI-PAM; Heinz Walz GmbH, Effeltrich, Germany).

\subsection{Statistical Analysis}

All chlorophyll fluorescence-related data were subjected to a two-way analysis of variance (ANOVA). The data were further subjected to a multiple comparison by $\mathrm{Tu}-$ key's test to clarify the effects of $\mathrm{O}_{3}$ concentrations with elapsing dark adaptation period. Statistical analyses were performed using Excel Statistics 2010 for Windows software package (Social Survey Research Information Co. Ltd., Tokyo, Japan). Differences among treated samples were considered statistically significant at $\mathrm{P} \leq 0.05$ or $\mathrm{P} \leq$ 0.01 compared with non-treated plant group at each time interval. Appropriate standard errors of the means (SE) were calculated, and the results are presented as line graphs.

\section{Results}

In Exp. 1, we were concerned about the different re- 
sponses of the two applied fluorometers. The $F_{0}, F_{\mathrm{m}}$ and $F_{\mathrm{v}} / F_{\mathrm{m}}$ values measured using one fluorometer (MINIPAM) were slightly lower than those measured using the other fluorometer (LI-6400-40); however, the trends were similar (Figure 1). Thus, we employed MINI-PAM fluorometer in the replicate experiment (Exp. 2) because it was easier to carry than the LI-6400-40 fluorometer. The $F_{\mathrm{v}} / F_{\mathrm{m}}$ ratio was lowest at $\mathrm{D}^{0}$ in all treatments, and $F_{\mathrm{v}} / F_{\mathrm{m}}$ was found to be decreased in an $\mathrm{O}_{3}$-concentration-dependent manner. In the $\mathrm{O}^{0}$ plants, $F_{\mathrm{v}} / F_{\mathrm{m}}$ increased from $\mathrm{D}^{0}$ to $\mathrm{D}^{10}$ and was then nearly constant from $\mathrm{D}^{10}$ to $\mathrm{D}^{30}$. The $F_{\mathrm{v}} / F_{\mathrm{m}}$ ratio in the $\mathrm{O}^{0.1}$ plants increased from $\mathrm{D}^{0}$ to $\mathrm{D}^{10}$, as in the $\mathrm{O}^{0}$ plants, but then increased further after
$\mathrm{D}^{10}$. In the $\mathrm{O}^{0.3}$ plants, $F_{\mathrm{v}} / F_{\mathrm{m}}$ increased from $\mathrm{D}^{0}$ to $\mathrm{D}^{5}$ and then tended to decrease with the time in darkness (Figures 1(a) and (b)). $F_{0}$, a component of $F_{\mathrm{v}} / F_{\mathrm{m}}$, decreased slightly with the period of darkness in the $\mathrm{O}^{0}$ plants. In contrast, in the $\mathrm{O}^{0.3}$ plants, $F_{0}$ increased with the period of darkness: the $F_{0}$ measured at $\mathrm{D}^{30}$ had increased to $135 \%$ (MINI-PAM) - $154 \%$ (LI-6400-40) of its value at $\mathrm{D}^{0}$ (Figures 1(c) and (d)). $F_{\mathrm{m}}$, a component of $F_{\mathrm{v}} / F_{\mathrm{m}}$, was decreased by $\mathrm{O}^{0.3}$ though it substantially increased with the period of darkness (Figures 1(e) and (f)) . $\left(1 / F_{0}\right)$ - $\left(1 / F_{\mathrm{m}}\right)$, which is an indicator of PSII inactivation, increased in the $\mathrm{O}^{0}$ plants, was unchanged in the $\mathrm{O}^{0.1}$ plants, and decreased in the $\mathrm{O}^{0.3}$ plants with the period of dark-

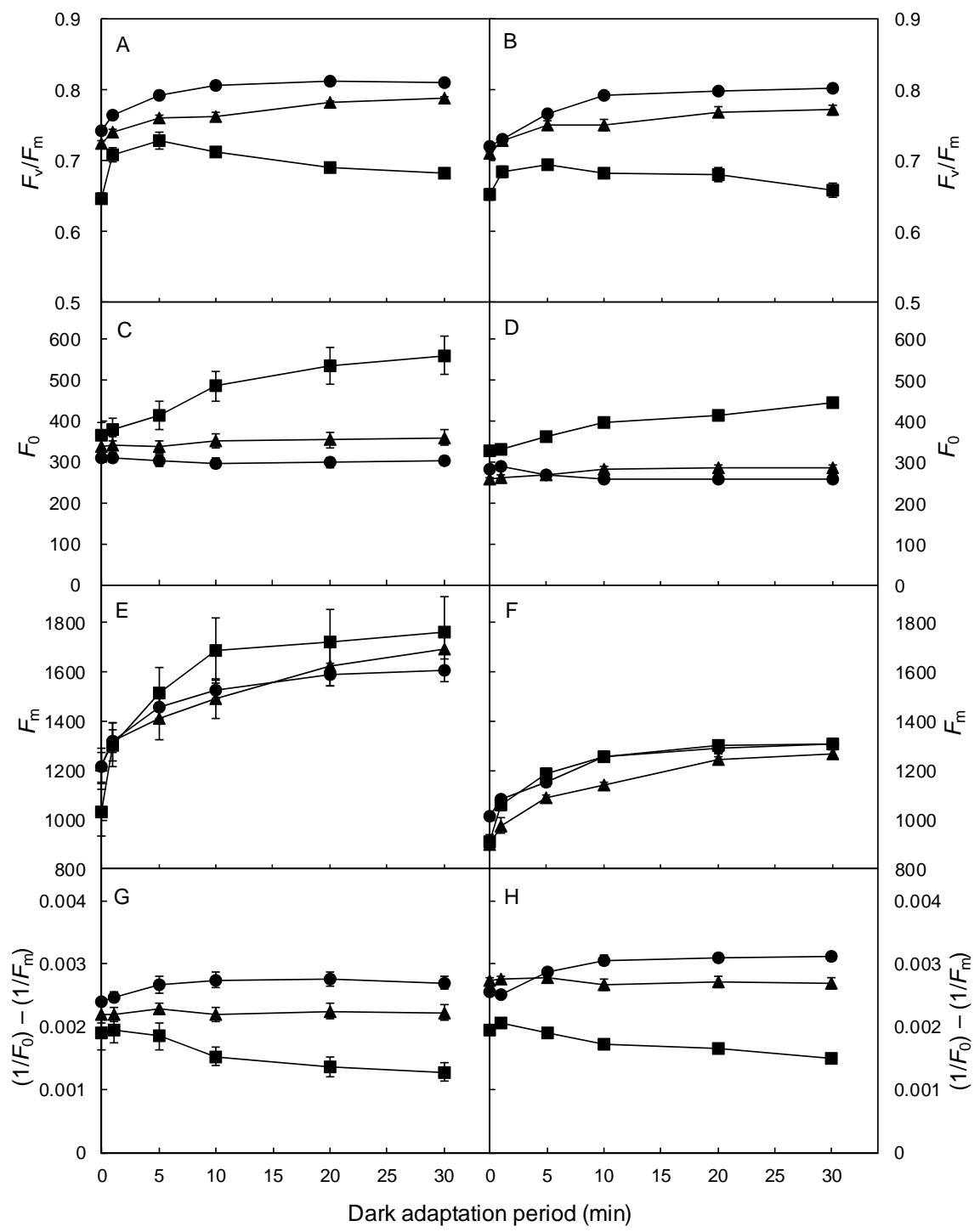

Figure 1. Effects of $\mathrm{O}_{3}$ on the maximum quantum efficiency of PSII $\left(F_{\mathrm{v}} / F_{\mathrm{m}}\right)$, minimum fluorescence $\left(F_{0}\right)$, maximum fluorescence $\left(F_{m}\right)$, and $\left(1 / F_{0}\right)-\left(1 / F_{m}\right)$ under different dark adaptation periods in rice leaves $(E x p$. 1$)$. The fluorescence parameters for $1 \mathrm{~A}, 1 \mathrm{C}, 1 \mathrm{E}$, and 1G were obtained using LI-6400-40 fluorometer, whereas those for 1B, 1D, 1F, and 1H were obtained using MINI-PAM fluorometer. The vertical bars represent the standard errors of the mean $(n=5) . \bullet, \Delta, \varpi: 0,0.1$, and 0.3 $\mathrm{cm}^{-3} \cdot \mathrm{m}^{-3} \cdot \mathrm{O}_{3}$. 
Table 1. Statistical analyses of the effects of $\mathrm{O}_{3}$ and dark adaptation period on chlorophyll fluoresence parameters in rice leaves. ${ }^{*} p<0.05, * * p<0.01, * * * p<0.001$. n.s., not significant by two-way ANOVA. $F_{0}$, minimal fluorescence in the dark-adapted state; $F_{m}$, maximal fluorescence in the dark adapted state; $F_{v} / F_{m}$, maximal quantum efficiency of PSII.

\begin{tabular}{|c|c|c|c|c|c|}
\hline Experiment & Factor & $F_{\mathrm{v}} / F_{\mathrm{m}}$ & $F_{0}$ & $F_{\mathrm{m}}$ & $\left(1 / F_{0}\right)-\left(1 / F_{m}\right)$ \\
\hline \multirow[t]{3}{*}{ Exp. 1 (LI-6400XT) } & $\mathrm{O}_{3}$ & $* * *$ & $* * *$ & n.s. & $* * *$ \\
\hline & dark adaptation period & $* * *$ & $*$ & $* * *$ & n.s. \\
\hline & $\mathrm{O}_{3} \times$ dark adaptation period & $* * *$ & $* *$ & n.s. & n.s. \\
\hline \multirow[t]{3}{*}{ Exp. 1 (MINI-PAM) } & $\mathrm{O}_{3}$ & $* * *$ & $* * *$ & $* * *$ & $* * *$ \\
\hline & dark adaptation period & $* * *$ & $* * *$ & $* * *$ & n.s. \\
\hline & $\mathrm{O}_{3} \times$ dark adaptation period & $* * *$ & $* * *$ & n.s. & $* * *$ \\
\hline \multirow[t]{3}{*}{ Exp. 2 (MINI-PAM) } & $\mathrm{O}_{3}$ & $* * *$ & $* * *$ & $* * *$ & $* * *$ \\
\hline & dark adaptation period & $* * *$ & $* *$ & $* * *$ & $* * *$ \\
\hline & $\mathrm{O}_{3} \times$ dark adaptation period & $*$ & $* * *$ & n.s. & $* * *$ \\
\hline
\end{tabular}

Table 2. Statistical analyses of the chlorophyll fluoresence parameters in rice leaves between control plants $\left(\mathrm{O}^{0}\right)$ and $\mathrm{O}_{3}$-treated plants $\left(\mathrm{O}^{0.1}\right.$ or $\left.\mathrm{O}^{0.3}\right)$ under different dark adaptation periods. ${ }^{*} p<0.05$, $* * p<0.01$, $* * * p<0.001$. n.s., not significant by Turkey's test. $F_{0}$, minimal fluorescence in the dark-adapted state; $F_{m}$, maximal fluorescence in the dark adapted state; $F_{\mathrm{v}} / F_{\mathrm{m}}$, maximal quantum efficiency of PSII.

\begin{tabular}{|c|c|c|c|c|c|c|c|c|}
\hline \multirow[t]{2}{*}{ Experiment } & \multirow[t]{2}{*}{ Parameter } & \multirow[t]{2}{*}{$\mathrm{O}_{3}\left(\mathrm{~cm}^{3} \cdot \mathrm{m}^{-3}\right)$} & \multicolumn{6}{|c|}{ Dark adaptation period (min) } \\
\hline & & & 0 & 1 & 5 & 10 & 20 & 30 \\
\hline \multirow[t]{8}{*}{ Exp. 1 (LI-6400XT) } & $F_{\mathrm{v}} / F_{\mathrm{m}}$ & $\mathrm{O}^{0.1}$ & n.s. & n.s. & n.s. & $* * *$ & $* *$ & $*$ \\
\hline & & $\mathrm{O}^{0.3}$ & $* * *$ & $* *$ & $* * *$ & $* * *$ & $* * *$ & $* * *$ \\
\hline & $F_{0}$ & $\mathrm{O}^{0.1}$ & n.s. & n.s. & n.s. & n.s. & n.s. & n.s. \\
\hline & & $\mathrm{O}^{0.3}$ & n.s. & n.s. & $*$ & $* *$ & $* * *$ & $* * *$ \\
\hline & $F_{\mathrm{m}}$ & $\mathrm{O}^{0.1}$ & n.s. & n.s. & n.s. & n.s. & n.s. & n.s. \\
\hline & & $\mathrm{O}^{0.3}$ & n.s. & n.s. & n.s. & n.s. & n.s. & n.s. \\
\hline & $\left(1 / F_{0}\right)-\left(1 / F_{\mathrm{m}}\right)$ & $\mathrm{O}^{0.1}$ & n.s. & n.s. & n.s. & $*$ & n.s. & n.s. \\
\hline & & $\mathrm{O}^{0.3}$ & n.s. & n.s. & $*$ & $* * *$ & $* * *$ & $* * *$ \\
\hline \multirow[t]{7}{*}{ Exp. 1 (MINI-PAM) } & $F_{\mathrm{v}} / F_{\mathrm{m}}$ & $\mathrm{O}^{0.1}$ & n.s. & n.s. & n.s. & $* *$ & $*$ & $*$ \\
\hline & $F_{0}$ & $\mathrm{O}^{0.1}$ & $* *$ & $* *$ & n.s. & n.s. & n.s. & n.s. \\
\hline & & $\mathrm{O}^{0.3}$ & $* * *$ & $* * *$ & $* * *$ & $* * *$ & $* * *$ & $* * *$ \\
\hline & $F_{\mathrm{m}}$ & $\mathrm{O}^{0.1}$ & $*$ & $*$ & $*$ & $* *$ & n.s. & n.s. \\
\hline & & $\mathrm{O}^{0.3}$ & $*$ & n.s. & n.s. & n.s. & n.s. & n.s. \\
\hline & $\left(1 / F_{0}\right)-\left(1 / F_{\mathrm{m}}\right)$ & $\mathrm{O}^{0.1}$ & $* *$ & $* *$ & n.s. & $* *$ & $*$ & $* *$ \\
\hline & & $\mathrm{O}^{0.3}$ & $* * *$ & $* * *$ & $* * *$ & $* * *$ & $* * *$ & $* * *$ \\
\hline \multirow[t]{7}{*}{ Exp. 2 (MINI-PAM) } & $F_{\mathrm{v}} / F_{\mathrm{m}}$ & $\mathrm{O}^{0.1}$ & n.s. & n.s. & $*$ & $* * *$ & $* *$ & $* *$ \\
\hline & & $\mathrm{O}^{0.3}$ & $* * *$ & $* *$ & $* * *$ & $* * *$ & $* * *$ & $* * *$ \\
\hline & $F_{0}$ & $\mathrm{O}^{0.1}$ & n.s. & n.s. & $* *$ & $* *$ & $* *$ & $*$ \\
\hline & & $\mathrm{O}^{0.3}$ & $* *$ & $*$ & $*$ & $* * *$ & $* * *$ & $* * *$ \\
\hline & $F_{\mathrm{m}}$ & $\mathrm{O}^{0.1}$ & n.s. & n.s. & $*$ & $* * *$ & $* *$ & $* *$ \\
\hline & $\left(1 / F_{0}\right)-\left(1 / F_{\mathrm{m}}\right)$ & $\mathrm{O}^{0.1}$ & n.s. & n.s. & $* *$ & $* * *$ & $* * *$ & $* * *$ \\
\hline & & $\mathrm{O}^{0.3}$ & n.s. & n.s. & $* * *$ & $* * *$ & $* * *$ & $* * *$ \\
\hline
\end{tabular}


ness (Figures 1(g) and (h)). Statistical analyses (Tables 1 and 2) examining the $\mathrm{O}_{3}$ inhibition of $F_{\mathrm{v}} / F_{\mathrm{m}}, F_{0}, F_{\mathrm{m}}$, and $\left(1 / F_{0}\right)-\left(1 / F_{\mathrm{m}}\right)$ support the description provided above regarding the fluorometers (LI-6400-40 and MINIPAM), with special reference to the dark adaptation period.

In Exp. 2, $F_{\mathrm{v}} / F_{\mathrm{m}}$ was found to be decreased by $\mathrm{O}_{3}$ treatment, while $F_{0}$ was increased (Figures 2(a) and (b)), as observed in Exp. 1. However, the trend found for $F_{\mathrm{m}}$ differed from that observed in Exp. 1. The value of $F_{\mathrm{m}}$ recovered dramatically with the period of darkness; however, because the decrease that occurred at $\mathrm{D}^{0}$ was more pronounced than in Exp. 1, this recovery was insufficient (Figure 2(c)). $\left(1 / F_{0}\right)-\left(1 / F_{\mathrm{m}}\right)$ was decreased by $\mathrm{O}_{3}$ treatment, as in Exp. 1, and this value decreased gradually with the period of darkness in the $\mathrm{O}^{0.3}$ plants (Figure 2(d)).

Statistical analyses (Tables 1 and 2) of the results obtained using a single fluorometer (MINI-PAM) supported the existence of differential responses to early dark adaptation periods in the two experiments. In Exp. 2, $F_{0}, F_{\mathrm{m}}$, and $\left(1 / F_{0}\right)-\left(1 / F_{\mathrm{m}}\right)$ showed lower significant levels than those of Exp. 1 when compared to each of the control plants $\left(\mathrm{O}^{0}\right)$ at early dark adaptation periods.

\section{Discussion}

Consistent with the results of a previous study by our group [5], $F_{\mathrm{v}} / F_{\mathrm{m}}$ was found to be adversely affected by $\mathrm{O}_{3}$ in the present study. The $F_{\mathrm{v}} / F_{\mathrm{m}}$ ratios in all plants were lowest at $\mathrm{D}^{0}$. In the $\mathrm{O}^{0}$ and $\mathrm{O}^{0.1}$ plants, $F_{\mathrm{v}} / F_{\mathrm{m}}$ recovered with the period of darkness, however, because $F_{\mathrm{v}} / F_{\mathrm{m}}$ decreased gradually with the period of darkness in the $\mathrm{O}^{0.3}$ plants, we inferred that the inhibition of PSII by $\mathrm{O}_{3}$ was exacerbated (Figures 1(a), (b) and 2(a)). $F_{\mathrm{v}} / F_{\mathrm{m}}$ decreases when $\mathrm{F}_{0}$ increases and/or $F_{\mathrm{m}}$ decreases (i.e., $F_{\mathrm{v}}$ $\left.=F_{\mathrm{m}}-F_{0}\right)[18,19]$. In the present study, the $F_{0}$ values recorded in the $\mathrm{O}^{0.1}$ and $\mathrm{O}^{0.3}$ plants were generally higher than in the $\mathrm{O}^{0}$ plants at all measurement times, and the values increased gradually with the progression of dark adaptation (Figures 1(c), (d) and 2(b)). Previous studies in snap bean [20,28] and Betula pendula [24] support the current results that $F_{0}$ was increased by $\mathrm{O}_{3}$ exposure. The increase in $F_{0}$ and decrease in $F_{\mathrm{m}}$ are induced by the inhibition of electron transport from $Q_{\mathrm{A}}$ to $Q_{\mathrm{B}}$ and the oxygen-evolving system from the manganese cluster to the tyrosine residue of the D1 protein, respectively [19]. Therefore, it appeared that the damage that occurred to PSII in the $\mathrm{O}^{0.3}$ plants was induced mainly by the inhibition of electron transport from $Q_{\mathrm{A}}$ to $Q_{\mathrm{B}}$. In addition, as $\left(1 / F_{0}\right)-\left(1 / F_{m}\right)$ was found to be decreased in the $O^{0.3}$ plants with the period of darkness (Figures 1(g), (h) and 2(d)), PSII was gradually inactivated even during dark adaptation. However, $F_{\mathrm{m}}$ was observed to be decreased by $\mathrm{O}_{3}$ treatment at any measurement time in Exp. 2. The $F_{\mathrm{v}} / F_{\mathrm{m}}$ obtained at $\mathrm{D}^{0}$ in Exp. 2 was lower than in Exp. 1. As the $\mathrm{O}_{3}$-induced decrease in $F_{\mathrm{m}}$ observed in Exp. 2 (Figure 2(c)) was more pronounced than that in Exp. 1 (Figures 1(e) and (f)), it is possible that the detrimental

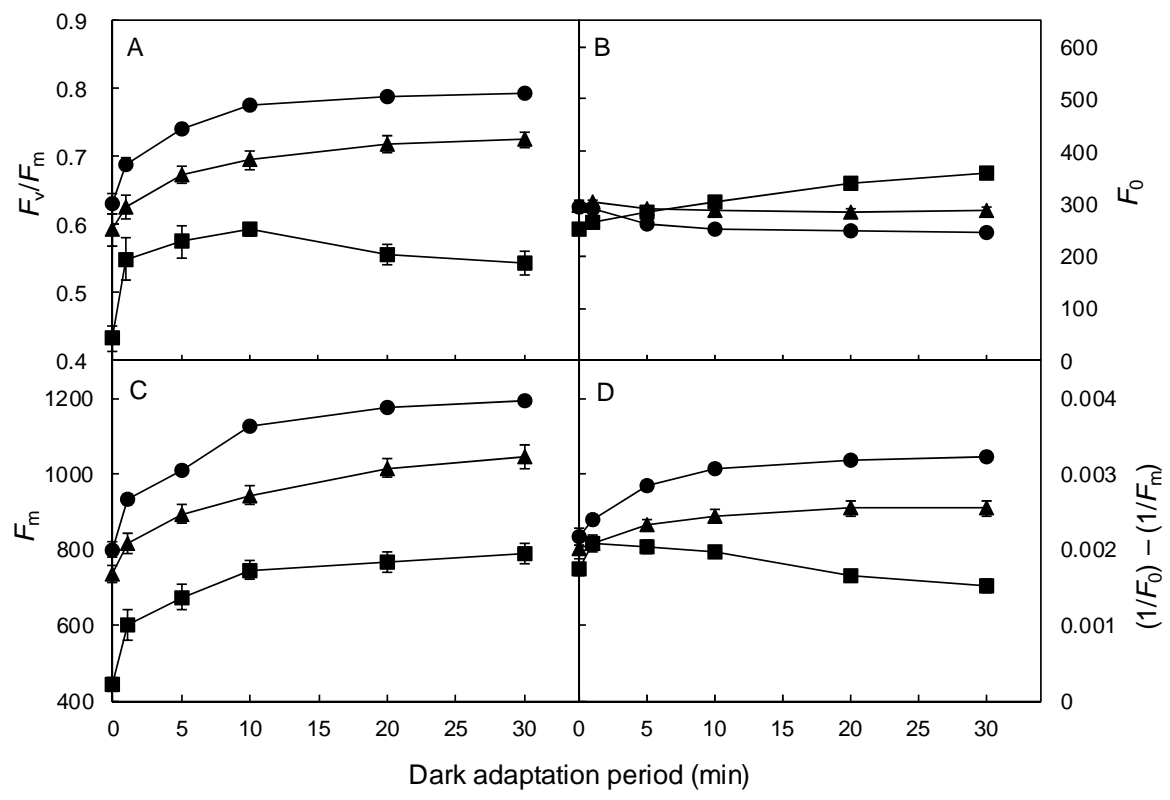

Figure 2. Effects of $\mathrm{O}_{3}$ on the maximum quantum efficiency of PSII $\left(F_{\mathrm{v}} / F_{\mathrm{m}}\right)$, minimum fluorescence $\left(F_{0}\right)$, maximum fluorescence $\left(F_{m}\right)$, and $\left(1 / F_{0}\right)-\left(1 / F_{m}\right)$ under different dark adaptation periods in rice leaves $($ Exp. 2$)$. The fluorescence parameters were obtained using MINI-PAM fluorometer. Vertical bars represent the standard errors of the mean $(n=5) . \bullet, \Delta, \bullet: 0,0.1$, and $0.3 \mathrm{~cm}^{-3} \cdot \mathrm{m}^{-3} \cdot \mathrm{O}_{3}$. 
effect of $\mathrm{O}_{3}$ was more pronounced in Exp. 2 due to the higher light intensities involved. In fact, the PPFD values recorded at 12:00 $\mathrm{h}$ in the natural light growth chamber were approximately 900 and $1100 \mu \mathrm{mol} \cdot \mathrm{m}^{-2} \cdot \mathrm{s}^{-1}$ in Exp. 1 and Exp. 2, respectively. Guidi et al. [23] also observed that the inhibition of $P_{\mathrm{N}}$ and PSII activity by $\mathrm{O}_{3}$ was greater under high light intensities $\left(30-1000 \mu \mathrm{mol} \cdot \mathrm{m}^{-2}\right.$. $\mathrm{s}^{-1}$ PPFD). Similarly, Kobayakawa and Imai [32] reported that the intercepted radiation is a major determining factor in $\mathrm{O}_{3}$ inhibition. While the decrease in $F_{\mathrm{v}} / F_{\mathrm{m}}$ was induced by an increase in $F_{0}$ in the present study, in previous studies, a decrease in $F_{\mathrm{v}} / F_{\mathrm{m}}$ was found to be induced by a decrease in $F_{\mathrm{m}}$ in $\mathrm{O}_{3}$-exposed lettuce [25] and tobacco [26]. Guidi et al. [22] measured the effect of $\mathrm{O}_{3}$ on chlorophyll fluorescence in 14 bean cultivars and reported that the cause of the inhibition of $F_{\mathrm{v}} / F_{\mathrm{m}}$ (e.g., increased $F_{0}$ and/or decreased $F \mathrm{~m}$ ) depended on the cultivar. Interestingly, the $F_{\mathrm{v}} / F_{\mathrm{m}}$ was found to be decreased by both an increase in $F_{0}$ and a decrease in $F_{\mathrm{m}}$ in chronically $\mathrm{O}_{3}$-exposed rice leaves [7]. Therefore, the cause of the decrease in $F_{\mathrm{v}} / F_{\mathrm{m}}$ depends on the species, cultivar, and environmental conditions involved.

$F_{\mathrm{v}} / F_{\mathrm{m}}$ is determined without irradiating actinic light. Therefore, the obtained values can only be decreased by the non-photochemical quenching coefficient $\left(q_{\mathrm{N}}\right)$. Three major components of $q_{\mathrm{N}}$ have been identified in plant leaves in vivo: the energy $(\Delta \mathrm{pH})$-dependent quenching coefficient $\left(q_{\mathrm{E}}\right)$, photoinhibitory quenching coefficient $\left(q_{\mathrm{I}}\right)$, and state-transition quenching coefficient $\left(q_{\mathrm{T}}\right)$. The relaxation kinetics of these components differ: the half time $\left(\mathrm{t}_{1 / 2}\right)$ is $1 \mathrm{~min}$ for $q_{\mathrm{E}}, 5-10 \mathrm{~min}$ for $q_{\mathrm{T}}$, and $>30 \mathrm{~min}$ for $q_{\mathrm{I}}[16,17]$. Because $q_{\mathrm{T}}$ is suppressed under strong light, it should not be regarded as a photoprotective mechanism. In this study, the leaves of the plants were exposed to $\mathrm{O}_{3}$ during sunny daytime hours. Therefore, $F_{\mathrm{v}} / F_{\mathrm{m}}$ was decreased mainly by $q_{\mathrm{E}}$ and $q_{\mathrm{I}}$. $q_{\mathrm{I}}$ includes the xanthophyll cycle-dependent component and inactivation of the D1 protein component. The relaxation time of these two components differs: the $t_{1 / 2}$ of the former is shorter than $30 \mathrm{~min}$, whereas that of the latter is longer than $1 \mathrm{~h}$ $[16,17]$. In all plants, $F_{\mathrm{v}} / F_{\mathrm{m}}$ recovered dramatically from $\mathrm{D}^{0}$ to $\mathrm{D}^{1}$ (Figures 1(a), (b) and 2(a)). This recovery was likely induced by the relaxation of $q_{\mathrm{E}}$. Consequently, in addition to the $\mathrm{O}^{0.1}$ and $\mathrm{O}^{0.3}$ plants, a decrease in $F_{\mathrm{v}} / F_{\mathrm{m}}$ caused by $q_{\mathrm{E}}$ also occurred in the $\mathrm{O}^{0}$ (control) plants. Furthermore, as the degree of recovery observed in the $\mathrm{O}^{0.3}$ plants from $\mathrm{D}^{0}$ to $\mathrm{D}^{1}$ was higher than in the $\mathrm{O}^{0}$ and $\mathrm{O}^{0.1}$ plants, $q_{\mathrm{N}}$ was increased by a higher $\mathrm{O}_{3}$ concentration $\left(\mathrm{O}^{0.3}\right)$. Additionally, in the $\mathrm{O}^{0}$ plants, $F_{\mathrm{v}} / F_{\mathrm{m}}$ did not change from $\mathrm{D}^{10}$ onward (Figures 1(a), (b) and 2(a)). Consequently, it appeared that $q_{\mathrm{I}}$ disappeared in the $\mathrm{O}^{0}$ plants during a $10 \mathrm{~min}$ period of dark adaptation. Thus, because $F_{\mathrm{v}} / F_{\mathrm{m}}$ decreased in the $\mathrm{O}^{0}$ plants prior to $\mathrm{D}^{5}$, it is difficult to distinguish the effects of $\mathrm{O}_{3}$ and other factors (e.g., light) prior to this time point. As $F_{\mathrm{v}} / F_{\mathrm{m}}$ recovered in the $\mathrm{O}^{0.1}$ plants (increased) from $\mathrm{D}^{10}$ to $\mathrm{D}^{20}$, the xanthophyll cycle-dependent quenching (fast relaxation phase) of $q_{\mathrm{I}}$ would also have been increased during that time. Consequently, if the dark adaptation period is greater than $20 \mathrm{~min}$, the effects of $\mathrm{O}_{3}$ on the fast relaxation phase of $q_{\mathrm{I}}$ will disappear. However, when only the effects on D1 protein inactivation are to be evaluated, leaves must be maintained for more than $20 \mathrm{~min}$ in the dark. In the $\mathrm{O}^{0.3}$ plants, $F_{\mathrm{v}} / F_{\mathrm{m}}$ decreased as the dark adaptation period progressed from $\mathrm{D}^{5}$. Therefore, if the dark adaptation period is too long, $F_{\mathrm{v}} / F_{\mathrm{m}}$ might differ from the value obtained immediately after $\mathrm{O}_{3}$ exposure.

The results of these experiments imply that the optimum dark adaptation period for evaluating $F_{\mathrm{v}} / F_{\mathrm{m}}$ of PSII in $\mathrm{O}_{3}$-exposed rice leaves is $10 \mathrm{~min}$ because the effect of $\mathrm{O}_{3}$ is maximal at this time, and the effects of other factors on $F_{\mathrm{v}} / F_{\mathrm{m}}$ disappear.

\section{Acknowledgements}

This work was supported by a grant for the Private University Strategic Infrastructure Formation Support Project (No. S0901028) and a Grant-in-Aid for Challenging Exploratory Research (No. 23658019) from the MEXT, Japan.

\section{REFERENCES}

[1] Environ Improve Div, Tokyo Metropolitan Government Bureau Environ, "Review Report on the Photochemical Oxidant Measures," Journal of Japan Society for Atmospheric Environment, Vol. 40, No. 6, 2005, pp. A65-A77.

[2] H. Cabrera, S. V. Dawson and C. Stromberg, "A California Air Standard to Protect Vegetation from Ozone," Environmental Pollution, Vol. 53, No. 1-4, 1988, pp. $397-$ 408. doi:10.1016/0269-7491(88)90049-8

[3] I. Nouchi, "Plant Responses to Atmospheric Environmental Change," Yokendo, Tokyo, 2001.

[4] K. Imai and K. Kobori, "Effects of the Interaction between Ozone and Carbon Dioxide on Gas Exchange, Ascorbic Acid, and Visible Leaf Symptoms in Rice Leaves,' Photosynthetica, Vol. 46, No. 3, 2008, pp. 387-394. doi:10.1007/s11099-008-0070-4

[5] H. Kobayakawa and K. Imai, "Effects of the Interaction between Ozone and Carbon Dioxide on Gas Exchange, Photosystem II and Antioxidants in Rice Leaves," Photosynthetica, Vol. 49, No. 2, 2011, pp. 227-238. doi:10.1007/s11099-011-0024-0

[6] T. Ishioh and K. Imai, "Effects of Atmospheric Ozone and Carbon Dioxide Concentrations on Gas Exchanges, Contents of Rubisco and Chlorophyll in Leaves of Lowland Rice," Proceeding of Kanto Branch, Crop Science Society of Japan, Vol. 20, 2005, pp. 54-55. 
[7] R. Rai and M. Agrawal, "Evaluation of Physiological and Biochemical Responses of Two Rice (Oryza sativa L.) Cultivars to Ambient Air Pollution Using Open Top Chambers at a Rural Site in India," Science of the Total Environment, Vol. 407, No. 1, 2008, pp. 679-691. doi:10.1016/j.scitotenv.2008.09.010

[8] H. Kobayakawa and K. Imai, "Effects of $\mathrm{O}_{3}$ and $\mathrm{CO}_{2}$ on Photosystem II, Nitrate Reductase and Nitrite Reductase in Paddy Rice Leaves," Environment Control in Biology, Vol. 49, No. 2, 2011, pp. 91-98. doi:10.2525/ecb.49.91

[9] S. Toyama, M. Yoshida, T. Niki, T. Ohashi and I. Koyama, "Studies on Ultrastructure and Function of Photosynthetic Apparatus in Rice Cells. IV. Effects of Low Dose and Intermittent Fumigation of Ozone on the Ultrastructure of Chloroplasts in Rice Leaf Cells," Japanese Journal of Crop Science, Vol. 58, No. 4, 1989, pp. 664672.

[10] K. Imai and T. Ookoshi, "Elevated $\mathrm{CO}_{2}$ Ameliorates $\mathrm{O}_{3}$ Inhibition of Growth and Yield in Paddy Rice," Environment Control in Biology, Vol. 49, No. 2, 2011, pp. 7582. doi: $10.2525 /$ ecb. 49.75

[11] I. Nouchi, O. Ito, Y. Harazono and H. Kouchi, "Acceleration of ${ }^{13} \mathrm{C}$-Labelled Photosynthate Partitioning from Leaves to Panicles in Rice Plants Exposed to Chronic Ozone at the Reproductive Stage," Environmental Pollution, Vol. 88, No. 3, 1995, pp. 253-260. doi:10.1016/0269-7491(95)93437-5

[12] C. D. Reid and E. L. Fiscus, "Ozone and Density Affect the Response of Biomass and Seed Yield to Elevated $\mathrm{CO}_{2}$ in Rice," Global Change Biology, Vol. 14, No. 1, 2008, pp. 60-76. doi:10.1111/j.1365-2486.2007.01472.x

[13] J. Pang, K. Kobayashi and J. Zhu, "Yield and Photosynthetic Characteristics of Flag Leaves in Chinise Rice (Oryza sativa L.) Varieties Subjected to Free-Air Release of Ozone," Agriculture Ecosystems and Environment, Vol. 132, No. 3-4, 2009, pp. 203-211. doi:10.1016/j.agee.2009.03.012

[14] E. A. Ainsworth, G. R. Yendrek, S. Sitch, W. J. Collin and L. D. Emberson, "The Effects of Tropospheric Ozone on Net Primary Productivity and Implications for Climate Change," Annual Review of Plant Biology, Vol. 63, 2012, pp. 637-661. doi:10.1146/annurev-arplant-042110-103829

[15] A. Bhatia, R. Tomer, V. Kumar, S. D. Singh and H. Pathak, "Impact of Tropospheric Ozone on Crop Growth and Productivity-A Review," Journal of Scientific and Industrial Research, Vol. 71, No. 2, 2012, pp. 97-112.

[16] W. W. Adams III and B. Demming-Adams, "Chlorophyll Fluorescence as a Tool to Monitor Plant Response to the Environment," In: G. C. Papageorgiou and Govindjee, Eds., Chlorophyll a Fluorescence: A Signature of Photosynthesis. Advances in Photosynthesis and Respiration, Springer, Dordrecht, 2004, pp. 583-604.

[17] G. H. Krause and P. Jahns, "Non-Photochemical Energy Dissipation Determined by chlorophyll Fluorescence Quenching: Characterization and Function," In: G. C. Papageorgiou and Govindjee, Eds., Chlorophyll a Fluorescence: A Signature of Photosynthesis. Advances in Pho- tosynthesis and Respiration, Springer, Dordrecht, 2004, pp. 463-495.

[18] N. R. Baker, "Chlorophyll Fluorescence: A Probe of Photosynthesis in Vivo," Annual Review of Plant Biology, Vol. 59, 2008, pp. 89-113.

doi:10.1146/annurev.arplant.59.032607.092759

[19] K. Sonoike, "Basics of the Measurements of Photosynthesis by Pulse Amplitude Modulation," Low Temperature Science, Vol. 67, 2009, pp. 507-524.

[20] E. H. Lee, "Chlorophyll Fluorescence as an Indicator to Detect Differential Tolerance of Snapbean Cultivars in Response to $\mathrm{O}_{3}$ Stress," Taiwania, Vol. 36, No. 3, 1991, pp. 220-234.

[21] L. Guidi, C. Nali, S. Ciompi, G. Lorenzini and G. F. Soldatini, "The Use of Chlorophyll Fluorescence and Leaf Gas Exchange as Methods for Studying the Different Responses to Ozone of Two Bean Cultivars," Journal of Experimental Botany, Vol. 48, No. 1, 1997, pp. 173-179. doi: $10.1093 / \mathrm{jxb} / 48.1 .173$

[22] L. Guidi, R. Di Cagno and G. F. Soldatini, "Screening of Bean Cultivars for Their Response to Ozone as Evaluated by Visible Symptoms and Leaf Chlorophyll Fluorescence," Environmental Pollution, Vol. 107, No. 3, 2000, pp. 349-355. doi:10.1016/S0269-7491(99)00170-0

[23] L. Guidi, M. Tonini and G. F. Soladatini, "Effects of High Light and Ozone Fumigation on Photosynthesis in Phaseolus vulgaris," Plant Physiology and Biochemistry, Vol. 38, No. 9, 2000, pp. 717-725. doi:10.1016/S0981-9428(00)01172-4

[24] S. Shavnin, S. Maurer, R. Matyseek, W. Bilger and C. Scheidegger, "The Impact of Ozone Fumigation and Fertilization on Chlorophyll Fluorescence of Birch Leaves (Betula pendula)," Trees, Vol. 14, No. 1, 1999, pp. 10-16. doi:10.1007/s004680050002

[25] A. Calatayud, J. M. Ramirez, D. J. Iglesias and E. Barreno, "Effects of Ozone on Photosynthetic $\mathrm{CO}_{2}$ Exchange, Chlorophyll Fluorescence and Antioxidant Systems in Lettuce Leaves," Physiologia Plantarum, Vol. 116, No. 3, 2002, pp. 308-316. doi:10.1034/j.1399-3054.2002.1160305.x

[26] E. Degl'Innocenti, L. Guidi and G. F. Soldatini, “Characterisation of the Photosynthetic Response of Tobacco Leaves to Ozone: $\mathrm{CO}_{2}$ Assimilation and Chlorophyll Fluorescence," Journal of Plant Physiology, Vol. 159, No. 8, 2002, pp. 845-853. doi:10.1078/0176-1617-00519

[27] J. Skotnica, M. Gilber, I. Weingart and C. Wilhelm, "Thermoluminescence as a Tool for Monitoring OzoneStressed Plants," Environmental Pollution, Vol. 123, No. 1, 2003, pp. 15-20. doi:10.1016/S0269-7491(02)00365-2

[28] M. D. Flowers, E. L. Fiscus, K. O. Burkey, F. L. Booker and J.-B. Dubois, "Photosynthesis, Chlorophyll Fluorescence, and Yield of Snap Bean (Phaseolus vulgaris L.) Genotypes Differing in Sensitivity to Ozone," Environmental and Experimental Botany, Vol. 61, No. 2, 2007, 190-198. doi:10.1016/j.envexpbot.2007.05.009

[29] L. Wang, X. He and W. Chen, "Effects of Elevated Ozone on Photosynthetic $\mathrm{CO}_{2}$ Exchange and Chlorophyll a Fluo- 
rescence in Leaves of Quercus mongolia Grown in Urban Area," Bulletin of Environmental Contamination and Toxicology, Vol. 82, No. 4, 2009, pp. 478-481. doi:10.1007/s00128-008-9606-3

[30] J. R. Haun, "Visual Quantification of Wheat Development," Agronomy Journal, Vol. 65, No. 1, 1973, pp. 116119.

[31] M. Havaux, R. J. Strasser and H. Greppin, "A Theoretical and Experimental Analysis of $\mathrm{q}_{\mathrm{P}}$ and $\mathrm{q}_{\mathrm{N}}$ Coefficients of
Chlorophyll Fluorescence Quenching and Their Relation to Photochemical and Nonphotochemical Events," Photosynthesis Research, Vol. 27, No. 1, 1991, pp. 41-55. doi:10.1007/BF00029975

[32] H. Kobayakwa and K, Imai, "Inclination Angle Affects Ozone Injury in the Flag Leaf of Rice," Plant Production Science, Vol. 16, No. 1, 2013, pp. 24-30. doi: $10.1626 /$ pps. 16.24 